DOI: $10.33766 / 2524-0323.95 .287-304$

УДК 343.2:340.132(477)(094.4)

Розовский Б. Г., доктор юридических наук, профессор, заслуженный юрист Украины, заведующий кафедрой правоведения Восточноукраинского национального университета имени В. Даля (2. Северодонеик, Украина)

e-mail: rozovskiy@rambler.ru

ORCID iD : https://orcid.org/0000-0002-5087-7076

\title{
«РВАНЫЕ» НОРМЫ УГОЛОВНОГО КОДЕКСА
}

Уголовное право считается замыкающей отраслью права («Последний довод короля»). На деле многочисленные запреты норм Уголовного кодекса определяют пределы правового регулирования позитивных отраслей права, выстраивая «Великую китайскую стену», зачастую препятствующую реализации прогрессивных начинаний. Предупреждение такой опасности должно проходить красной нитью в готовящемся проекте УК Украины.

В действующем праве человек зачастую заменен роботом. В противовес этому в уголовном праве субъектом ответственности является человек со всеми его биологическими и социальными особенностями. Стандартизация здесь недопустима.

Ключевые слова: проект Уголовного кодекса Украины, верховенство права, робот, мотив и цель преступления, труднообъяснимое влечение к физической опасности, компульсивное поведение, «рваность норм кодекса».

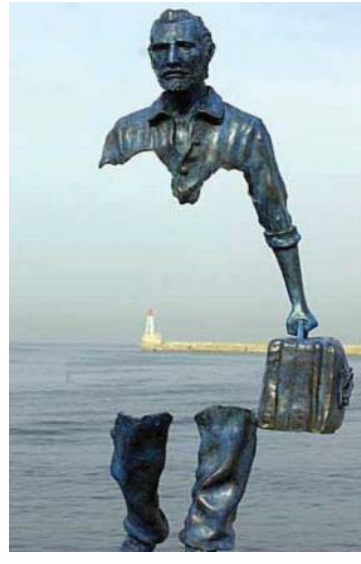

Философы во всех исследованиях трубят о том, что человечество вступило в фазу никогда ранее не ведомого интенсивного изменения окружающего его мира. Апогеем стало массовое появление неведомой ранее новации - роботов, которые во многих сферах, вплоть до секса, заменяют живого человека ${ }^{1}$.

Цели роботизации многоплановы. Выделю показательную в плане дальнейшего изложения. Прогнозируется, что с развитием чипирования и других технологий грань между человеком и роботом может в определенной мере сократиться: в ряде производств робот будет действовать по заранее спрогнозированным и заложенным программам, что позволит исключить человеческий фактор в сложных операциях.

1 Настоящая статья является попыткой продолжить дискуссию с разработчиками проекта нового УК Украины. См. : URL : https:/ / newcriminalcode.org.ua. (дата обращения: 05.09.2021) 
Естественно, подобные концепции не остаются без критики, зачастую, безжалостной. Оснований достаточно. Но, на удивление, главный, основополагающий методологический провал оказался в тени, замалчивается всеми, в том числе и юристами. Не буду вдаваться в подробности, констатирую парадокс: есть сфера общественных отношений, где уже тысячелетиями человек выступает в роли безукоризненного робота. И не один-два субъекта, сто или миллион, а подавляющая часть человечества. Она очевидна: это сфера государственного законодательного регулирования жизни и деятельности человека от рождения до смерти, а в наследовании даже позже. Если вдуматься, мы живем в мире, в какой-то части познанном, а больше - выдуманном законодателем, заранее смодулировавшим все мыслимые и немыслимые ситуаци для обычных людей, которых принято называть среднестатистическими. Государство извечно, не всегда логично пытается регулировать каждый шаг, каждый вздох человека, предписывая, что ему можно делать и что нельзя, а если можно, то как и в каких границах. Показательный пример из недалекого прошлого. Знаменитый кинорежиссер Сергей Бондарчук состоял в браке с актрисой Инной Макаровой, но к тому времени у него был восьмилетний внебрачный сын Алексей. Бондарчук решил оформить своё отцовство. Для этого ему пришлось расторгнуть брак с Макаровой, официально расписаться с мамой Алёши, признать его своим сыном, после чего расторгнуть этот однодневный брак и вновь жениться на Макаровой 1.

Изменились времена, однако законодательные нравы не только сохранились, но приобрели еще более уродливые формы. Поделюсь собственным опытом. После трагических событий на Донбассе я приобрел ущербный статус переселенца. Чтобы получать украинскую пенсию, для идентификации потребовалось получить электронную карточку, выдаваемую сроком на два года. Получил ее я в Николаеве, куда первоначально выехал из Луганска. Условия жизни там были неблагоприятные, и мой старый друг проявил гостеприимство: предложил переехать в его дом в Чернигове, с официальной пропиской. С благодарностью предложение было принято. В Чернигов из Николаева было переслано мое пенсионное дело. Спустя время, меня пригласили заведовать кафедрой Восточноукраинского национального университета имени Владимира Даля в г. Северодонецке. Предложение принял. Пенсионное дело не переводил, ибо никто этого не требовал. Но истекли два года, меня обязали сменить электронную карточку. И началась эпопея.

От меня потребовали лично явиться в Николаев для закрытия электронной карточки. Я обратился в областное управление «Ощадбанка» в Северодонецке с просьбой провести эти операции по месту моего пребывания. Получил отказ. Приехал в Киев в главный офис «Ощадбанка». Там с трудом согласились не отсылать меня в Николаев, но обязали ехать в Чернигов. Приехал. В Черниговском областном отделении «Ощадбанка» провели «сложнейшую» процедуру: у меня

1 За рубежом не лучше. Согласно закона штата Айова длительность поцелую не должна превышать 5 минут. В штате Арканзас муж имеет право бить жену, но не чаще одного раза в месяц. Источник: Социальная сеть для зрелых людей. URL : https://24pixelnews.com/novosti/23-13-samykhnelepykh-za konov-ssha/8. 
взяли заявление сделали копии с паспорта и идентификационного кода. В главном офисе «Ощадбанка» в Киеве, где я «проторчал» более часа, сделать это не смогли.

Через две недели меня вновь вызвали в Чернигов: нужно было пойти в Пенсионный фонд, взять оформленный к этому времени документ и отнести его в «Ощадбанк». Через полтора месяца надо еще раз пересечь страну с юго-востока на северо-запад, чтобы забрать злополучную карточку (переслать ее в Северодонецк или вручить по нотариально удостоверенной доверенности моему другу, авторитетному человеку в области, категорически отказали... Идиотский закон, но закон!). Все это происходит в век интернета и начинающейся оцифровки информации. (Отмечу, отечественные кухарки потому и управляют государством, что им все расписано).

Я недаром акцентировал внимание на том, что в нашей стране сфера государственного законодательного регулирования жизни и деятельности человека роботизирована. Уже писал, но, памятуя, что «капля точит камень не силой, а частым падением», вынужденно повторяю: образно говоря, закон - это чурка, из которой еще предстоит вырезать Буратино. Без этого закон - грубое полено, которым бьют по головам без ума и толку. Скрупулезное соблюдение закона превращает его в вариант Мидаса. Закон обретает жизнь в праве. Реальная жизнь человека и человечества в целом состоит не из запретов, а из неисчислимых возможностей. Право и толкуется в обыденном сознании как свобода, разрешение иметь что-то, поступать желаемым образомํ․ В 60-е годы, когда во Франции шли бунты договорились до того, что «свобода - это запретить запрещать». Можно все. Сейчас к этому относятся с иронией, но рациональное зерно в этом есть. Стоит ли все безоговорочно запрещать, если в реальной действительности редко какое правило не требует выявляемых в процессе его применения разного рода исключений. По большому счету, прогресс - это результат преодоления множества запретов. Недаром говорят, что все великие открытия сделали хулиганы ${ }^{2}$. В действительности мы во многом руководствуется правом - формой добровольного согласования способов решения жизненно важных проблем. Отнюдь не в единичных случаях право при этом вступает в противоречие с законом. Более того, оно повседневно служит, своего рода, ситом, через которое просеивается закон. Достаточно вспомнить, по-

1 Ричард Гир как-то сказал: «Каков был бы мир, если в нем нельзя было сделать что-то не так, если бы в нем не было запретов, сладостей, белого вина и красного мяса. Ради чего бы мы жили? В наших слабостях наша сила». "Помните, времени мало" / 3 поразительные цитаты Ричарда Гира для тех, кому за 50. Источник : SkVer.

2 «Брэнсон, я тебе гарантирую, что ты или сядешь в тюрьму, или станешь миллионером», - сказал директор школы, выпуская в жизнь одного из самых неугомонных учеников. Ричард Брэнсон оправдал ожидания, стал миллиардером, побывавшим в космосе:/ Ахмирова Р. Хиппи-миллиардер Ричард Брэнсон: пять историй о знаменитом богаче-фрике. [Интернет-источник] Собеседник. 12.07.2021. URL : https:/ / sobesednik.ru/kultura-i-tv/20210712-xippi-milliarder-ricard-brenson-pyat-is/. 
лучившие известность, так называемые «итальянские забастовки». В 1904 году итальянские железнодорожники изобрели новый способ бастовать. Во-первых, умерили свой итальянский темперамент. Всё стало делаться гораздо медленнее. Вовторых, начали соблюдать ВСЕ технические инструкции и регламенты, прописанные работодателем. Таким образом, дирекции и предъявить было нечего. Железная дорога «встала». Поезда были отменены, хотя, формально, все работали.

С подобным результатом проходили итальянские забастовки диспетчеров аэропортов, которые в повседневной работе дополняли, изменяли, совершенствовали должностные инструкции с учетом специфики местных условий, реальной нагрузки аэропорта, типов самолетов, осуществляющих взлет - посадку, и даже квалификации пилотов [1].

В народном юморе находят образное отражение реальные хозяйственные и иные операции, когда пунктуальное соблюдение закона затруднено. «Одна семья жила бедно, но славилась на всю округу своей честностью и справедливостью. А кормило их нежнейшее масло, которое делала жена. По утрам женщина изготавливала его в круглых формах, и каждый сливочный диск весил один килограмм. Муж продавал продукт знакомому бакалейщику, а на вырученные средства покупал в лавке все необходимое, включая спички, хлеб и сахар. Но как-то раз бакалейщик заподозрил неладное! Ему показалось, что очередная партия, которую принёс бедняк, весит меньше, чем обычно. Лавочник не поленился и взвесил каждый круг. Действительно, их вес был ровно на 100 граммов меньше положенного. Бакалейщик пришел в ярость, но решил подождать следующего дня.

И вновь бедняк пришел к нему, чтобы продать сливочный продукт. Торговец гневно высказал ему свои претензии:

- Как ты мог! Мы договаривались, что ты будешь поставлять мне масло весом в килограмм. А ты обманул меня: каждый круг весит не больше 900 граммов! Можешь больше не приходить сюда, я найду другого поставщика! - кричал толстяк, потрясая кулаками.

Было видно, что бедняк удивлен и расстроен. Впрочем, мужчина не растерялся и ответил:

- Господин, мы слишком бедны, чтобы иметь весы. И всякий раз, покупая у тебя килограмм сахара, я делал его своей мерой, по которой взвешивал масло».

Это притча, однако за ней жизнь, плохая или хорошая, но во многом реальная. В системе государственного регулирования подобные бакалейщики и производители масла неминуемо должны стать субъектами уголовного процесса есть норма, есть нарушение, независимо от причин, должен быть результат. Отечественное современное уголовное право является идеальным воплощением общей конструкции права, где человек исчез - его место занял бездушный абсолютизированный робот.

Нормы уголовного кодекса - это уникум, идеальным отражением которого может служить популярная серия «рваных» скулыптур Бруно Каталано. (Одна из них отображена в начале статьи.) Его «вояжеры»- разных возрастов, полов, национальностей - представляют собой образы путешественников со странной, на первый взгляд, «пустотой внутри». Это намек художника на то, что современные динамичные, вечно куда-то спешащие люди, только и представляют собой, что 
ноги, голову и чемодан, без целостности внутри, без ощущения внутреннего дома, как было когда-то [2].

Аналогия убедительна. Нормы Уголовного кодекса столь же «рваные» - это конструктивная форма, бездушный каркас набора всяких ограничений, превращающих жизнедеятельность живого гражданина - с его бедами, заботами, попытками реализовать себя в освоении природы, улучшении организации общества - в стандартизированного по не всегда понятной логике типичного робота. Здесь есть только механическая оболочка предаваемого суду. Никакой души, ничего живого, способного вызвать отклик на реальную жизнь, нет и в помине.

Приходится сожалеть, что разработчики проекта УК Украины живут в прошлом, продолжая традиционно исповедовать догмы многовековой практики. Признаюсь, не был удивлен, когда ознакомился на сайте разработчиков проекта УК Украины с их реакцией на разумные замечания В. Н. Сущенко о недопустимости игнорировать при определении наказания за преступление мотивов и целей его совершения. Она, в известной мере, отражает ущербность идеологии, и даже психологии, разработчиков Проекта, выступающих в роли представителя сильного пола в известной байке: «По каким параметрам женщины выбирают шампунь? - Марка, эффективность, запах, состав, цвет, качество, дизайн упаковки, рекомендации, отзывы, реклама, известность. - А по каким параметрам мужчины выбирают шампунь? - На этикетке должно быть написано «шампунь».

Рецензент пишет: «Отказ в отдельных случаях от установки «мотива и цели» правонарушения (п.7), как обязательного элемента состава преступления - «вины», приводит и, кажется, будет приводить к нарушению принципов «справедливости и пропорциональности» при определении «виновности/невиновности» и соответствующей меры наказания лищу.

Субъективную сторону состава уголовного правонарушения определяют признаки, характеризующие вину субъекта уголовного правонарушения, а в случаях, предусмотренных в статьях особенной и общей частей Кодекса, мотив, цель и особое психоэмоциональное состояние этого субъекта во время совершение им уголовного правонарушения».

В ответ В. А. Навроцкий безапелляционно заявил: «Если правильно понял замечание, его автор считает, что мотив и цель являются обязательными признаками, присущими составу любого преступления. Но это же не так, обязательными являются те признаки, которым законодатель придал такое значение. Или, может, В. Н. Сущенко считает, что мотив и цель являются составляющими вины? Но и с этим согласиться нельзя: вина - отношение к уже совершенному, мотив и цель то, что предшествует преступлению, что «толкает» к его совершению. Поэтому их отождествлять нельзя. Связь того, что мотив и цель не признаются обязательными признаками состава с нарушением принципов «справедливости и соразмерности при ...», также не понял. Может, имеется в виду необходимость/целесообразность их учета и в случаях, когда мотив и цель не являются признаками состава преступления? Но ведь установление состава преступления (квалификация) и определение наказания - это различные этапы правоприменения, установление обязательных признаков состава является предпосылкой определение наказания» [3]. 
Может, и надо уточнить редакцию соответствующих статей Проекта. Но можно ли оспаривать суть: цель и мотив практически в большинстве являются психологической основой для образования у субъекта виновного отношения к совершаемому деянию? Л. Е. Владимиров писал: «Входит или не входит по закону мотив данного преступления в понятие последнего, он должен быть непременно выявлен. Мотив есть истинный источник преступления, и никогда просвещенный суд не удовлетворится следствием, не раскрывшим мотива преступления. Объясняя возникновение данного преступления, мотив имеет глубокое значение для психологического понимания деяния, а в случаях сильного душевного волнения подсудимого он представляет важный опорный пункт для заключения врача-психиатра» [4]. Но Л. Е. Владимиров для разработчиков кодекса не указ.

Я, в прошлом следователь и прокурор с многолетним стажем, не представляю, как можно судить о вине правонарушителя, не выяснив цель и мотив его совершения. На завершающей стадии вина является основанием для вынесения наказания. Но она выясняется с момента принятия заявления от потерпевшего о совершенном преступлении, и на всем протяжении расследования. И по многим преступлениям без мотива и цели совершения преступления ясную картину получить невозможно.

С. Н. Сущенко безоговорочно прав, утверждая, что их игнорирование будет приводить к нарушению принципов «справедливости и пропорциональности» при определении «виновности/невиновности» и соответствующей меры наказания лицу». Жаль, что его доводы не восприняты.

Формальная казуистика В. А. Навроцкого, если она разделяется остальными разработчиками УК, не столь безвредна. Игнорируя необходимость/целесообразность учета мотива и цели в случаях, когда они не являются обязательными признаками состава преступления, «которым законодатель придал такое значение», мы приходим к обесчеловеченью уголовного права. Уголовный кодекс закономерно может рассматриваться как произведение жанра хоррор, где фантастика, став явью, предназначена устрашить, напугать своих читателей, вызвав у них чувства ужаса и шока. Ни о каком сострадании к оступившимся речи быть не может.

Оценивая потуги разработчиков проекта УК, невольно вспоминаешь анекдот: «На море едешь со своей женой? - Нет, в путевке написано, что все включено». Кодекс пытаются представить универсальным законом с решениями на все случаи жизни. Однако тысячелетняя история убедительно свидетельствует: универсальные методы уголовного права пригодны только для противодействия стандартной преступности. Исследователи констатируют, что развитие права в нашем недалёком прошлом, как и сейчас, осуществлялось в основе своей на условном уровне - в форме «науки слов», а не науки реалий. Мы не имеем сколько-нибудь адекватного прогноза возможного развития преступности. Более того, эти проблемы научно не изучаются. Законы разрабатываются не на основе фундаментального анализа и прогноза реалий - научно не исследуется, не прогнозируется их возможная фактическая эффективность действия. Мы привыкли ко всему этому «незнанию», как к стихии.

Известный нобелевский лауреат немецкий физик и философ М. Планк убеждал, что существует лишь то, что можно измерить. Именно поэтому считается, 
что любая реальная наука начинается с измерения. Академик В. Садовничий прямо сказал, что на юридических факультетах стоило бы преподавать курс общей математики, философию математики и логику, назвав это ключевым. Не пора ли подумать, советовал он, над математической моделью Гражданского кодекса, Уголовного кодекса, потому что сегодня соотношение разных норм, например, Уголовного кодекса, с его точки зрения, начисто лишено логики и здравого смысла? [5] К сожалению, слова остались словами, ничего для реализации предложения не сделали. В Украине не ставится даже такой вопрос.

Современное общество находится на новом витке своего развития. Глобализация ведет к формированию общих и единых моделей поведения людей. Украина стремится к сближению с западными моделями социального поведения. Реальная жизнь многогранна и многолика, спрогнозировать всё и вся наперед практически невозможно. Поэтому формулы многих норм Кодекса целесообразно проектировать с учетом потенциала новых решений.

Подвижность уголовной политики ожидается с неизбежным признанием судебной практикой цивилизованной формулы: правосудие - это когда судят не заведомого преступника, а человека, нарушившего закон. Однако в уголовном праве, при всех теоретических изысках, личность, уровень сознания человека, его способность оценивать совершенное деяние далеко не на первом плане. А различия между людьми в этом плане порой непредсказуемы.

Показательный пример. В конце шоу аргентинский фокусник Марво попросил своего ассистента выстрелить ему в голову из ружья. Грохнул выстрел - и Марво, торжествуя, вытащил пулю изо рта (фокус, видимо, был рассчитан на детей дошкольного возраста). Тем не менее, присутствующий в зале золотодобытчик Марко Аспрелла был восхищен трюком и со словами: «А поймайте-ка эту!» - выстрелил в голову фокусника из своего пистолета. Маг долго не мучился. На суде Аспрелла выглядел подавленным и никак не мог понять, почему фокусник не поймал его пулю... Он был оправдан [6].

Аспреллы есть не только в Аргентине и, отнюдь, не в единичном количестве. Надо честно признать, при оценке их поведения в основе лежит критерий «вменяем - невменяем», без достаточной проработки. До критического проявления такие люди не являются объектами исследования и наблюдения. Может, надо начинать издалека - с анализа причин, почему в 2021 году 31,1 \% участников ВНО (внешнего независимого оценивания знаний) среди выпускников украинских школ не справились с тестовым заданием по математике, меньшая часть - по другим предметам, не сумев набрать даже минимального количества баллов?

Показательно решение проблемы в Израиле. Корреспондент пишет: «Когда у меня начались сложности с успеваемостью, - мне на два дня вызвали психолога. Тесты показали, что у меня дисграфия (расстройство навыков письма, которое проявляется невозможностью или трудностью в соотнесении звуков устной речи и букв, их звучания и начертания), после чего орфографические ошибки перестали влиять на мои оценки. Не исключаю, что без такой корректировки у меня могли бы возникнуть серьёзные психологические проблемы, которые непонятно как отразились бы на моём отношении к школе и соученикам. Ребят с психиче- 
скими отклонениями вычисляли сразу. Кроме того, любая шалость, или, как нынче говорят, малейшее проявление девиантного поведения, сразу фиксировалась в личном деле учащегося. Причём эта информация никуда потом не пропадала с ней впоследствии могли ознакомиться врачи, полицейские, члены приёмных комиссий вузов, а также кадровики госкомпаний. Самую серьёзную проверку израильские юноши проходят при призыве в армию. Досье, собранное в школе, там изучают от и до. К тому же, спецслужбы ещё могут что-то добавить от себя. В Израиле ты весь на виду» [7].

Опыт, безусловно, заслуживает применения в Украине, где информация о таких рисках, как наркомания, алкоголизм, хулиганские проявления и т.Д., разбросана по разным ведомствам: о чём-то знают врачи, о чём-то - полиция.

Направления девиантного поведения множатся, и далеко не все учитываются при разработке уголовного и другого законодательства. Так британский психоаналитик Б. Карра, проанализировавший сексуальные фантазии 23 тыс. нормативных мужчин и женщин, заявил: «Если бы мы реализовывали свои фантазии, большая часть из нас оказалась бы за решёткой». Этому явлению мы в первую очередь обязаны порнографии, к которой наши современники приобщаются уже в начальной школе. А всё благодаря интернету. Каждое шестое посещение сети является заходом на порносайты, 80 \% контента даркнета - это детская порнография [8]. Реализация многих фантазий - вопрос времени.

Мы постоянно боремся за единообразие, непременно хотим, чтобы наше мнение было всеобщим. Но подлинно цивилизованное общество состоит из личностей, с их индивидуальными интересами и стремлениями, потребностями в определенной свободе действий. Порочно, когда с сожалением приходится говорить: «Хорошо иностранщу: он и у себя дома иностранец». Интересы государства не могут игнорироваться, но их нарушения нельзя дальше оценивать автоматически по заранее заданной схеме. На первый план выдвигается чисто человеческий, не боюсь характеристики, обывательский подход к оценке причины - почему этот конкретный человек нарушил закон? И здесь мы отнюдь не редко сможем увидеть: вину правонарушителя должно разделить государство, поставившее его в неблагоприятные жизненные условия, которые он не смог преодолеть.

Моему коллеге, в прошлом судье, пришлось рассматривать дело о краже молодым отцом нескольких листов металла. Он вспоминал: «Семья испытывала вынужденные трудности». На вопрос о причине хищения, виновный пояснил: «Я прихожу домой, а маленький сын спрашивает: «Папа, ты принес конфетку?». До сих пор помню, как он это произнес. Признаюсь, я сказал прокурору: «Забери дело на доследование, осудить этого человека не могу» [9, с. 37]». Подобные жизненные ситуации отнюдь не единичны, но понимание их разработчиками УК не просматриваются.

Не сомневаюсь в том, что отечественные корифеи прекрасно осведомлены о зарубежном уголовном законодательстве. Однако оно, как и отечественное, постоянно пополняется и совершенствуется. Информационной системы, которая бы своевременно выявляла и учитывала новации, у нас, видимо, нет. Одним из свидетельств является ограниченность использования в разделе 2.7. Проекта - «Обстоятельства, исключающие противоправность деяния», зарубежных новаций. А они 
есть, и весьма существенные. Например, ст. 16 УК КНР регламентирует: «Деяния, которые объективно хотя и привели к вредным последствиям, но были вызваны непреодолимой силой или невозможностью их предвидеть, не признаются преступными». Полагаю, аналогичная норма заслуживает включения в УК Украины.

Нельзя не осознавать противоречащие юридической теории, но справедливые истины уже осознают. К сожалению, не у нас. В Италии Высший суд разрешил голодным красть еду. В 2011 году безработного Острякова приговорили к шести месяцам заключения и штрафу в 100 евро за кражу двух кусков сыра и упаковки сосисок за четыре евро. Высший кассационный суд Италии отменил приговор и постановил, что кража продуктов для утоления голода не является преступлением. «Не подлежит наказанию тот, кто, будучи движимым нуждой, крадёт маленькое количество еды, чтобы удовлетворить жизненно важную потребность в пропитании», - говорится в постановлении суда. Решение Высшего кассационного суда является окончательным.

В уголовном праве при определении наказания оценивается внешнее поведение людей. Однако, по мере прогресса науки появляется возможность распознавать биологическую природу проступков. Задача неимоверно сложная. Геном человека включает в себя 30-35 тысяч генов. Изучены пока единицы. Не исключено, что мозг содержит еще какие-то биологические управляющие структуры. Но уже сейчас выявлены эксцессы, когда человек в здравом уме не в состоянии должным образом управлять своим поведением.

Шведские биологи выявили в головном мозге группу нервных клеток, отвечающих за принятие человеком решения об употреблении алкоголя, даже в том случае, когда здравый смысл подсказывает ему, что этого делать не надо. Результаты исследования опубликованы в журнале Science Advances. Большинство людей, употребляющих алкоголь, могут контролировать себя и воздерживаются от принятия спиртного в ситуациях, когда это может иметь негативные последствия. Но некоторые не могут удержаться. Интересно, что иногда в группу людей с таким, как говорят ученые, компульсивным поведением попадают и те, у кого нет явно выраженной алкогольной зависимости [10]. Полагаю, новация ожидает реакции разработчиков проекта УК при оценке степени вины совершивших преступление в состоянии алкогольного опьянения.

Известна не получившая должной оценки, патологическая, в моем понимании, предрасположенность ряда людей к чрезвычайному экстриму. С. В. Михалков написал: «Умный в гору не пойдет, умный гору обойдет». Но на деле идут, и отнюдь не единицы. На одном только Эвересте в 1983 г. на вершине побывали 8 человек, в 1990-е количество не превышало сорока в год, а в 2012-м - 234 человека за один день! 2018-й стал рекордным: весной на гору взошли 715 человек.

Эверест - это, в полном смысле слова, гора смерти. На нем погибли более десяти тысяч восходящих. Штурмуя эту высоту, алыпинист знает, что он рискует не вернуться. Гибель могут вызвать недостаток кислорода, сердечная недостаточность, обморожения или травмы. К смерти приводят и роковые случайности, вроде замерзшего клапана кислородного баллона. В зоне смерти действует негласное правило - каждый сам за себя. Если альпинисту становится плохо, он не может рассчитывать на чью-то помощь. На Эвересте группы альпинистов проходят 
мимо разбросанных непогребённых трупов (это трупы таких же альпинистов, только им не повезло). Кто-то из них сорвался и переломал себе кости, кто-то замерз или просто ослаб и всё равно замерз. Какая мораль может быть на высоте 8000 метров над уровнем моря?! Тут уж каждый за себя, лишь бы выжить! [11].

В Японии любители острых ощущений едят блюда из рыбы фугу. Она содержит яд, который считается лучшей приправой к готовому блюду. Смертельный яд - тетродотоксин - содержится в молоках, икре, на половых органах, коже и в печени фугу. Это вещество обладает нервнопаралитическим действием. Оно примерно в 1200 раз опаснее цианистого калия. Смертельная доза для человека составляет всего один миллиграмм тетродотоксина. В одной рыбке этого вещества хватит, чтобы убить сорок человек. Причем, эффективного противоядия до сих пор не существует.

Главная встреча человека с фугу происходит в ресторане. Здесь гурман буквально вверяет свою судьбу в руки повара. С 1598 года в Японии действует закон, который обязывает всех поваров по фугу получить лицензию. Для этого нужно пройти не только теоретическую подготовку и показать знание практических навыков, но и выполнить самое сложное испытание - съесть приготовленное блюдо. Так что плохие повара в Японии не задерживаются. Обязанность повара - бдительно следить за состоянием гостей, не позволяя им съесть больше безопасной дозы. Для этого необходимо не только знать тонкости приготовления этого блюда, но и обладать медицинскими знаниями, поскольку интенсивность воздействия яда зависит от комплекции, темперамента и даже цвета кожи клиента. Повара специально оставляют в готовом блюде небольшое количество яда. Именно это и обожают гурманы. Небольшая концентрация смертельного вещества создает ощущение легкого покалывания во рту и вызывает лёгкое одурманивание, которое сравнимо с опьянением. Психологический эффект - я принимаю яд!

Каждый год в Японии погибают 10-20 человек, которые ели эту рыбу. В большинстве эти люди погибают дома: пытаются сами приготовить фугу, но не справляются с задачей. Однако в их числе есть и посетители ресторанов. Японцы нашли способ получать фугу без яда. Спрос на нее упал! [12].

Еще один вид нестандартного поведения - рицепинг, трейсерфинг, зацепинг, запрыгивание на движущийся состав - это проезд снаружи поездов, опасный неформальный вид экстремального спорта. Лихачество подразумевает катание на крьшах поездов, с торцевой или боковой стороны состава либо на площадках перед задней кабиной электропоездов. Экстремал цепляется за выступающие поручни, лестницы, подножки, втискивается между вагонами, проезжают одну или две станции, при этом они снимают на видео свое безрассудство. Подростки, молодые люди или любители острых ощущений от 15 до 25 лет, практикующие подобные поездки, называются зацеперами или трейнсерферами.

Любители острых ощущений общаются между собой в соцсетях, создают сообщества, где ищут единомышленников, объединяются в неболышие группы для совместных поездок с целью пощекотать себе нервы. Среди любителей лихачества существуют свои традиции и негласные правила этики. Они организовывают массовые поездки, устраивают соревнования, снимают процесс на видео, и выклады- 
вают в интернете. Количество «пассажиров», практикующих проезд снаружи, исчисляется десятками тысяч. До 70 \% зацеперов гибнут в первые дни своего «увлечения». Опасный метод безбилетного проезда начинается игрой, а заканчивается трагедией [13].

Шоплифтеры - головная боль XXI века, абсолютно для всех магазинов и супермаркетов. Они способны вынести всё: от плитки шоколада до плазменного телевизора. Причем, ни охрана, ни даже прохожие не заметят. Занимаются этим отнюдь не только дети из бедных семей. Родители у шоплифтеров, как правило, зарабатывают выше среднего по стране, имеют квартиру и автомобиль, в общем, жаловаться не на что.

Это субкультура, зародившаяся в США еще в 40-ые годы прошлого века, когда только-только появились магазины самообслуживания (супермаркеты). Шоплифтеры себя позиционировали не как мелкие воришки, а как «освободители товаров». Это целая философия, которая идет наперекор всем канонам рыночного капитализма. Участники сего действа считают, что многие товары должны быть у людей бесплатно, и считают несправедливым десятикратную наценку продавца на товар.

Если обратиться к истории, труднообъяснимое влечение к физической опасности было у Пушкина и Лермонтова, заговорщика Гумилева. Стоит привести интересные рассуждения В. В. Шульгина - человека со сложной судьбой, видного государственного деятеля царской России: «В царской России, - вспоминал В. В. Шульгин, - яблок было много, и были они дешевы. Но и тогда мальчишки крали. Сейчас дела хуже. ... Плодокрадство - старинная русская привычка. Я сидел во Владимирской тюрьме с покойным князем Петром Дмитриевичем Долгоруковым как раз в то время, когда праздновалось 800-летие Москвы. Это было в 1947 году, осенью. Ставили постамент для памятника основателю Москвы Юрию Долгорукову, предку Петра Долгорукова, с которым я сидел. Ему было около 80 лет. Конец его был недалек, но он сохранил живость ума и ясность памяти. И он однажды сказал мне:

- Уверяю Вас, что Герцен (или Бакунин) был прав, когда говорил: «У русских бугор собственности не вытанцевался». Вот этому предку ставят памятник. За 800 лет, казалось бы, у Долгоруковых должна была бы пропасть охота красть, как Вы думаете?

- Срок достаточный!

- Так вот нет! Мне было лет десять, когда мы с матерью жили в Чехии. Почти каждый день мы ездили в экипаже в ближайший городок. Как все мальчишки, я любил влезать на козлы к кучеру, и мы с ним стали друзьями. Дорога, как все дороги в Чехии, была обсажена фруктовыми деревьями. Козлы высокие, вишни, сливы, потом яблоки были так близко, что я свободно мог бы их рвать. И, уверяю Вас, что я только потому их не крал, что мне стыдно было перед кучером. Подумайте! Ведь у нас за столом ежедневно были лучшие фрукты; не от фруктового голода я на них зарился, совсем нет; тут было какое-то атавистическое желание украсть, свойственное всем нам, у которых «бугор собственности не вытанщевался», в отличие от чехов. Поэтому-то и возможно было у них обсаживать дороги 
- никто не тронет. Нет, Вы вникните в эту трагедию, что чешский кучер был честнее, чем русский князь! Это у них, у чехов, такое отношение к чужой собственности было уже 100 лет тому назад. Как Вы думаете, через 100 лет от сего дня, то есть когда Москве будет 900 лет, можно ли будет обсаживать дороги фруктовыми деревьями?

Я сказал:

- Только в том случае, если всемогущая наука научит нас выращивать не только мичуринские сады, но и шишку собственности на лбу у русских мальчишек.

Не только у мальчишек! Как бывший помещик, я могу засвидетельствовать, что украсть у помещика не считалось ни грехом, ни преступлением. Крали фрукты из садов; дрова из леса; рыбу из прудов; муку из мельнищ; землю, снимая межевые знаки, и другими способами. Иногда мы защищались, но редко. На кражи рассчитывалось, как на другие расходы» [14].

Уважаемые коллеги, Вы уверены, что нет таких же биологических экстремалов, кроме маньяков и педофилов, среди тех, кого придают суду за совершение умышленных преступлений? Не они ли повторно совершающие преступления почти сразу по выходу из колонии? Не приписываем ли мы им видимую цель совершения преступления, вместо истинной биологической причины? Давайте поставим перед наукой задачу форсировать исследования в этом направлении, обяжем практиков избегать опасного формализма. Для биологически зависимых одно лишь уголовное наказание бессмысленно, в зависимости от тяжести содеянного, реально они требуют применения мер социальной защиты до блокирования зависимости.

Возможно, стоит проработать вариант с принудительным чипированием. Уже практикуется глубокая стимуляция мозга для страдающих болезнью Паркинсона. Популярное направление - восстановление зрения с помощью имплантов, которые помещают в зрительную кору. Как отмечают специалисты, в медицине это уже не дело будущего, а дело настоящего.

Правоведы не могут здесь быть посторонними наблюдателями. Пока же требуется разработать систему административного контроля за лицами, представляющими потенциальную общественную опасность.

Проектанты предусмотрели ответственность за вынесение заведомо незаконного и необоснованного судебного решения. Необходимость такой нормы бесспорна. Но, опять-таки, что такое необоснованное решение? В Америке, на которую ориентируемся, судьи не столь жестко связаны нормами закона. Известны примеры, когда виновные приговаривались к наказанию, вообее не предусмотренному действующим законодательством. Так женщина, оставившая новорожденных щенят в лесу (в США это уголовно наказуемое деяние), была приговорена пробыть в одиночестве в том же лесу одну ночь [15]. В отечественных судах подобные вольности исключены.

Известны и другие экзотические примеры. Во время Великой депрессии люди выживали всеми доступными способами. Пожилой нью-йоркский мусорщик решил стать фальшивомонетчиком. В отличие от профессиональных жуликов, которые подделывали крупные купюры, он начал кустарным образом у себя на 
кухне делать банкноты номиналом в один доллар. Когда в 1938 г. в секретную службу поступили первые фальшивки, детективы были потрясены. Во-первых, ни один уважающий себя фальшивомонетчик никогда не тратил время и силы на подделку 1-долларовых банкнот. Во-вторых, фальшивомонетчики обычно гордились своей работой: они были мастерами своего дела и старались сделать такие купюры, что их невозможно было бы отличить от настоящих денег. Но эти подделки были так ужасны, что секретная служба решила, что преступник просто издевается над ними. Деньги были напечатаны на самой дешевой бумаге, президент Вашингтон на них, по словам детективов, был «похож на смерть», а его фамилия была написана с ошибкой - «Wahsington».

Дело завели. Мошеннику дали имя «Мистер 880» из-за номера его дела. В течение месяца в криминалистической лаборатории появилось еще 40 таких же купюр. К середине 1938 года их число выросло до 585. Проблема была в том, что Мистер 880 был неуловим. Большинство фальшивомонетчиков губила жадность, но Мистер 880 никогда не тратил деньги в одном и том же месте дважды. И никогда не тратил более 15 фальшивых долларов в неделю. Следователи повесили огромную карту Нью-Йорка в своем офисе, отмечая место, в котором всплывали подделки, красной кнопкой. И скоро весь Нью-Йорк пламенел. Детективы напечатали и раздали около 200000 предупредительных листовок. Они проинструктировали более 10000 магазинов. Все было напрасно.

Годы шли, а поиск Мистера 880 превратился в самое дорогое расследование подделок в истории Секретной службы. Его поймали только в 1948 году. Совершенно случайно. В доме был пожар, и пожарные начали выбрасывать на улицу всякий хлам, который мог загореться. Там были и пробные клише, с которых печатали подделки.

Несмотря на незначительный номинал фальшивок, преступление Эриха относилось к категории тяжких. Теоретически он должен был получить от 30 лет до пожизненного заключения. Однако суд был впечатлен личностью преступника. Во время судебного заседания учли и возраст, и благородство в отношении жертв, и сотрудничество со следствием, и личное обаяние. В результате Эмерих Юнтер поставил еще один рекорд: он получил самый мягкий приговор среди всех фальшивомонетчиков.

Эмерих Юттнер оказался законопослушным гражданином. Он использовал свои фальшивые деньги только для покупки продуктов и предметов первой необходимости. Он никогда не обманывал ни одного продавца больше, чем на один доллар. Суд учел возраст преступника, незначительную сумму его подделок и приговорил Юттнера к штрафу в один доллар и тюремному заключению в один год и один день. Через четыре месяца Эмерих Юттнер вышел на свободу по УДО [16].

Еще необычный пример из так чтимой англосаксонской практики. 21-летнего Дэниела Гардмена приговорили к двум годам тюрьмы за то, что он бросил стакан во владельца бара. Усльшшав приговор, Гардмен разрыдался в зале суда. Судья Денис Кларк был искренне удивлен такой реакцией подсудимого. Он публично заявил, что верит в искренние раскаяния подсудимого, а значит, готов пе- 
ресмотреть вынесенный ему перед этим приговор. Наконец, вместо двух лет за решеткой, дебошира ждет лишь 200 часов принудительных работ и 500 фунтов компенсации, которую Дэниел должен выплатить обиженному им лицу [17].

Судья - человек, и все человеческое ему не чуждо. К сожалению, процессуальные требования закона порой ограничивают реализацию этих его качеств. Хотелось, чтобы разработчики проекта УК Украины минимизировали данный недостаток. Сведение имеющегося множества санкций к шести категориям - безусловный плюс. Можно надеяться, что в результате будущий УК хотя бы «похудеет». Но это чисто техническая мера. Недостаточно оставаться на поверхности, надо проникнуть в суть. В этом зарубежная судебная практика, отдельные примеры которой приведены, дает богатую пищу для творчества.

Есть резервы и отечественной практике. Насколько объективно, жизненно судьи оценивают личность подсудимого можно судить по динамике отмены и изменения приговоров. Однако есть еще один весьма весомый показатель - динамика условно досрочно освобожденных от дальнейшего наказания лиц его отбывающих. Если человека досрочно освобождают от отбытия наказания, возникает закономерный вопрос: зачем его суд изначально приговаривал к завышенному сроку? В принщипе Уголовный кодекс в большинстве норм не должен ограничивать минимальный размер санкций, предоставляя судье свободу выбора наказания.

Доводы допустимо множить. Можно привести еще ряд пробелов в проекте отечественного УК. Но пока это стрельба по непробиваемой цели: разработчики настолько уверены в своей позиции, что не считают нужным ответить на высказанные критические замечания. Не вижу активности и других коллег. (Может, причина в летних отпусках?). Поэтому, чтобы не нарушить допустимые рамки статьи, в заключение ограничусь одной ссылкой.

Отечественные ученые-юристы весьма часто заявляют, что в своих научных конструкциях они руководствуются верховенством права. При этом ориентированы на максимальную консолидацию отечественного законодательства с западным. Объявлено о проведении в таком ракурсе международной конференции под эгидой разработчиков проекта УК Украины. В принципе, я готов поднять стяг с призывом: «Да здравствует верховенство права!». Считаю только необходимьм оговорить, что поддерживаю именно желаемое верховенство права, а не фактически существующее у нас и исповедуемое разработчиками проекта УК Украины верховенство - на деле диктатуру закона со всеми присущими издержками.

Сразу заявляю, что верховенство права не означает тотальное нивелирование закона. Право призвано обеспечивать законность закона, его дееспособность и эффективность в решении жизненных задач. В этом право может защищать закон, примером чего служит эпопея с Конституционным судом Украины, который решением от 27 ноября 2020 года фактически уничтожил систему электронного декларирования, что привело к «дестабилизации социально-политической ситуации» и «дискредитации государства на международной арене», создало потенциальную угрозу госбезопасности.

Отчетность государственных чиновников о доходах (желательно и о расходах), конфискация незаконно нажитого является эффективным средством борьбы 
с коррупцией. В Гонконге такие меры были предприняты еще в 1974 году, в результате уровень коррущци в стране упал с 90 до 5-6 \%. Успехов достиг Китай. Учитывая недостаточную активность отечественных граждан в ликвидации проблемы, решение Конституционного суда не вызвало протестов, демонстраций, митингов - представляется целесообразным установить государством суровую уголовную ответственность за противодействие антикоррупционной деятельности.

Основатель гомеопатии Самюэль Ганеман еще в 1796 году установил показательный факт: лекарства, введенные в здоровый организм, оказывают на него воздействие, идентичное тому, какое вызывают болезни, причем, те, против которых и должна «работать» микстура. Жизнь, повседневная действительность свидетельствуют, что тот же отрицательный эффект мы получаем при имеющемся избытке правового регулирования. Однако данная закономерность столетиями находится вне поля внимания теоретиков права и законодателя.

Главное: если посмотреть рефераты по криминологии, наводнившие интернет, то почти каждый начинается с утверждения: «Лозунгом ученых до середины XX века было выражение Листа: «Не преступление, а преступник, не понятие, а человек». И хотя с тех пор прошло много лет, вопрос о том, кто и почему является преступником, остался».

Человек - самый уникальный и самый непознанный объект Вселенной. В целях верховенства права уголовное право обязано преодолеть традиционную косность и переориентироваться на регулирование с учетом познаваемых его биологических и психологических особенностей. Будущий УК должен обеспечивать справедливое наказание не роботизированному субъекту, а человеку со всеми бедами, мотивами, помыслами, приведшими его на скамью подсудимых. Для этого нормы УК требуется освободить от присущей им «рваности».

\section{Использованные источники:}

1. Розовский Б. Г. Уголовному Кодексу следует придать напоминание-эпиграф: «Многие расстрелянные были посмертно реабилитированы!» Актуальні проблеми права: теорія і практика. 2020. № 2(40). С. 196-200 ; Розовский Б. Г. Сизифов труд уголовного права. Актуальні проблеми права: теорія і практика. 2021. № 1(41). С. 31-46.

2. «Рваные» скулыптуры Бруно Каталано - Ярмарка Мастеров. [Электронный ресурc]. URL : https://www.livemaster.ru/topic/1129999-rvanye-skulptury-bruno-katalano. (дата обращения : 05.09.2021)

3. Новий Кримінальний Кодекс : Головна [вебсайт]. URL : https:/ / newcriminalcode. org.ua. (дата обращения: 05.09.2021)

4. Владимиров Л. Е. Advocatus miles. Пособие для уголовной защиты. Санкт-Петербурбг, 1911.230 с.

5. Лунеев В. В. Соотношение криминальных реалий с теорией права в России. Пролог : журнал о праве. 2014. Т. 2. № 4. С. 45-52.

6. Все шуточки : История [Электронный ресурс]. URL : https://vse-shutochki.ru/ istorya/1387.

7. Константин Поживилко. Выявить психа. [Электронный ресурс : Версия.]. URL : https://versia.ru/pochemu-v-izraile-nevozmozhny-rasstrely-v-shkolax. 
8. Интервью известного израильского религиоведа и писателя Арье Бараца, автора книги «Хартия сексуальной свободы». [Элек. ресурс]. URL : https://versia.sualnaya -ru.sekrevolyuciya-unichtozhit-evropejskuyu-demokratiyu.

9. Розовский Б. Г., Тагиев С. Р. Второй фронт криминологии: человек как социобиологический вид. Вісник Луганського державного університету внутрішніх справ імені Е.О. Дідоренка. 2019. Вип. 1 (85). С. 321-332.

10. Ученые раскрыли причину непреодолимой тяги к спиртному [Электронный pecypc]. URL : ria.ru>20210818/alkogol-1746250564.html.

11. Цель: Эверест: mr_gsv - LiveJournal. [Электронный ресурс]. URL : ivejournal. com/846557.html.

12. Рыба великая и ужасная. Фугу - великая и ужасная. [Электронный ресурс]. URL : https://pikabu.ru.

13. Зацеперы. Психологи на b17.ru. [Электронный ресурc]. URL : https://www. b17.ru.

14. Шульгин В. В. Опыт Ленина. 1958 г. [Электронный ресурс]. URL : https:/ / royallib.com>shulgin_vasiliy>opit_lenina.

15. «Креативные» наказания судьи из США. [Электронный ресурс]. URL : new sru.com>crime/08dec2005/sudja.html.

16. Кайдаш В. Мистер 880: Жизнь ценою в доллар. В Великобритании мужчину приговорили к самому короткому тюремному заключению в истории страны, сообщает Daily Mail. [Электронный ресурс]. URL : https://journal.open-broker.ru/history/ obman-na-odin-dollar/.

17. Telegraph. 6 июля 2006 г. [Электронный ресурc]. URL : https://www.inopressa. ru. (дата обращения : 05.09.2021)

\section{References:}

1. Rozovskij, B. G. $(2020,2021)$ Ugolovnomu Kodeksu sleduet pridat' napominanieepigraf: «Mnogie rasstrelyannye byli posmertno reabilitirovany!». Aktual'ni problemi prava: teoriya i praktika - Current issues of law: theory and practice, 2(40), 196-200 ; Rozovskij, B. G. (2021) Sizifov trud ugolovnogo prava. Aktual'ni problemi prava: teoriya i praktika - Current issues of law: theory and practice, 1(41), 31-46. [in Ukrainian].

2. «Rvanye» skul'ptury Bruno Katalano - YArmarka Masterov. [Elektronnyj resurs]. N. d. N. p. URL : https://www.livemaster.ru/topic/1129999-rvanye-skul ptury-bruno-katalano. [in Russian].

3. Novyi Kryminalnyi Kodeks : Holovna [vebsait]. N. d. N. p. URL : https:// newcriminalcode.org.ua. [in Ukrainian].

4. Vladimirov, L. E. (1911)Advocatus miles. Posobie dlya ugolovnoj zashchity. Sankt-Peterburbg. [in Russian].

5. Luneev, V. V. (2014) Sootnoshenie kriminal'nyh realij s teoriej prava v Rossii. Prolog : zhurnal o prave - Prologue: a magazine about law, vol. 2, 4, 45-52. [in Russian].

6. Vse shutochki : Istoriya [Elektronnyj resurs]. N. d. N. p. URL : https://vse-shutochki. $\mathrm{ru} /$ istorya/1387. [in Russian].

7. Konstantin Pozhivilko. Vyyavit' psiha. [Elektronnyj resurs: Versiya]. N. d. N. p. URL : https://versia.ru/pochemu-v-izraile-nevozmozhny-rasstrely-v-shkolax. [in Russian].

8. Interv'yu izvestnogo izrail'skogo religioveda i pisatelya Ar'e Baraca, avtora knigi «Hartiya seksual'noj svobody». [Elektronnyj resurs]. N. d. N. p. URL : https://versia.ru/seksualnaya-revolyuciya-unichtozhit-evropejskuyu-demokratiyu. [in Russian]. 
9. Rozovskij, B. G., Tagiev, S. R. (2019) Vtoroj front kriminologii: chelovek kak socio-biologicheskij vid. Visnik LDUVS im. E.O. Didorenka - Вісник ЛДУВС ім. Е.О. Дідоренка, іssие 1 (85), 321-332. [in Russian].

10. Uchenye raskryli prichinu nepreodolimoj tyagi k spirtnomu [Elektronnyj resurs]. $\mathrm{N}$. d. N. p. URL : ria.ru>20210818/alkogol-1746250564.html. [in Russian].

11. Cel': Everest: mr_gsv - Livejournal. [Elektronnyj resurs]. N. d. N. p. URL : ivejournal. com/846557.html. [in Russian].

12. Ryba velikaya i uzhasnaya. Fugu - velikaya i uzhasnaya. [Elektronnyj resurs]. N. d. N. p. URL : https://pikabu.ru >. [in Russian].

13. Zacepery. Psihologi na b17.ru. [Elektronnyj resurs]. N. d. N. p. URL : https:// www.b17.ru. [in Russian].

14. SHul'gin, V. V. (1958) Opyt Lenina. 1958 g. [Elektronnyj resurs]. N. p. URL : https:// royallib.com>shulgin_vasiliy>opit_lenina. [in Russian].

15. «Kreativnye» nakazaniya sud'i iz SSHA. [Elektronnyj resurs]. N. d. N. p. URL : newsru.com>crime/08dec2005/sudja.html. [in Russian].

16. Kajdash, V. Mister 880: ZHizn' cenoyu v dollar. V Velikobritanii muzhchinu prigovorili k samomu korotkomu tyuremnomu zaklyucheniyu v istorii strany, soobshchaet Daily Mail. [Elektronnyj resurs]. N. d. N. p. URL: https://journal.open-broker.ru/history/obman-na -odin-dollar/. [in Russian].

17. Telegraph. 6 iyulya 2006 g. [Elektronnyj resurs]. N. d. N. p. URL : https://www.inop ressa.ru. [in Russian].

Статья получена редколегией 06.09.2021

Розовський Б. Г., доктор юориичних наук, професор, заслужений юрист Украйни, завідувач кафедрою правознавства Східноукрайнського національного університету імені В. Даля (м. Сєвєродонецьк, Украӥна)

\section{«РВАНІ» НОРМИ КРИМІНАЛЬНОГО КОДЕКСУ}

Кримінальне право вважають замикальною галуззю права. («Останній аргумент короля»). Насправді численні заборони норм Кримінального кодексу визначають межі правового регулювання позитивних галузей права, вибудовуючи Велику китайську стіну, яка часто перешкоджає реалізації прогресивних починань. Попередження такої небезпеки має бути пріоритетним напрямком у підготовленому проекті КК України.

У чинному праві людину найчастіше замінюе робот. На противагу цьому в кримінальному праві суб'єктом відповідальності є людина з усіма їі біологічними і соціальними особливостями. Стандартізація тут неприпустима. Доводиться шкодувати, що розробники проекту КК України живуть у минулому, продовжуючи традищійно сповідувати догми багатовікової практики. У кримінальному праві, при всіх теоретичних вишукуваннях, особистість, рівень свідомості людини, ії здатність оцінювати вчинене діяння далеко не на першому місці. Припустима відмова в окремих випадках від установки «мотиву і мети» правопорушення (п.7) як обов'язкового елементу складу злочину - «провини», не враховується важкопояснюваний потяг деяких людей до фізичної небезпеки, що призводить до порушення принщипів «справедливості і пропорційності» при визначенні «винності/невинності» і відповідної міри покарання особі в кримінальному праві. 
Людина - найунікальніший і найбільш непізнаний об'єкт Всесвіту. 3 метою верховенства права кримінальне право зобов'язане подолати традиційну відсталість і переорієнтуватися на регулювання біологічних і психологічних його особливостей у процесі пізнання. Майбутній КК повинен забезпечувати справедливе покарання не роботизваному суб'єкту, а людині - з усіма бідами, мотивами, помислами, що привели її на лаву підсудних. Для цього норми КК потрібно звільнити від властивої їм «рваності».

Ключові слова: проект Кримінального кодексу України, верховенство права, робот, мотив і мета злочину, важкопояснюваний потяг до фізичної небезпеки, компульсивна поведінка, «рваність норм Кодексу».

Rozovskyi B., Doctor of Law, Professor, Honored Lawyer of Ukraine, Head of the Department of Law, V. Dahl East Ukrainian National University (Sievierodonetsk, Ukraine)

\section{«RIPPED» STANDARDS OF THE CRIMINAL CODE}

Criminal law is considered as a concluding branch of law ("The King's last argument"). In fact, numerous prohibitions of the Criminal Code define the limits of legal regulation of law positive branches, building the «Great Wall of China», which often hinders the implementation of progressive initiatives. Prevention of such a danger should be a priority in the prepared draft of the Criminal Code of Ukraine.

In the current law, a person is often replaced by a robot. In contrast, in criminal law, the subject of responsibility is a person with all his biological and social characteristics. Stndartization is unacceptable here.

We have to regret that the developers of the project of the Criminal Code of Ukraine live in the past, continuing to traditionally profess the dogmas of centuries-old practice. In criminal law, with all the theoretical research, the personality, level of human consciousness, his ability to evaluate the Committed Act is far from in the foreground.

It is allowed to refuse in some cases to establish the "motive and purpose" of the offense (paragraph 7), as a mandatory element of the corpus delicti - "guilt", it does not take into account the hard-to-explain attraction of some people to physical danger, which leads to a violation of the principles of "justice and proportionality" in determining "guilt/innocence" and the appropriate punishment of a person in criminal law.

Human is the most unique and unknown object in the universe. For the rule of law, criminal law must overcome traditional backwardness and reorient to the regulationt of its biological and psychological features in the process of cognition. The future Criminal Code must provide a fair punishment not for a robotic subject, but for a person with all the troubles, motives, and thoughts that led him to the dock. To do this, the rules of the Criminal Code must be freed from their inherent "ripped".

Keywords: project of the Criminal Code of Ukraine, the rule of law, robot, motive and purpose of the crime, difficult-to-explain attraction to physical danger, compulsive behavior, "ripped" of the norms of the Code. 